\title{
Restoration of mangrove co-management to sequester coastal blue carbon
}

\author{
Rudianto \\ Faculty of Fisheries and marine Science, \\ Brawijaya University, Malang, Indonesia
}

\begin{abstract}
Destruction of mangrove forests has become a major concern in Indonesia due to issues such as cutting for timber, fuel and charcoal. Mangroves are cleared for timber, charcoal and firewood. Because of higher calorific value, the mangrove twigs are used as firewood. To investigate whether mangrove restoration can absorb carbon and store it in the soil by using co-management approach, it is necessary to take the research sample in Jenu area, Tuban Regency, East Java Province, Indonesia. The condition of mangrove forest in coast of Jenu indicates the heavy degraded of mangrove forests. The purpose of this study, firstly, is building co-management model among stakeholders involved. Secondly, to describe the model of co management to restore mangrove forests to increase sequestering in coast of Jenu. The methodology used to achieve the research objective is using Generalized Structured Component Analysis (GSCA). GSCA offers a global least squares optimization criterion. The result of this study shows local government, community, and the private sector are working together to serve the public in an ethical and open manner that engenders accountability. Beside, the translation of co-management is based on 7 (seven) elements. they are a) equality in deliberation; (b) public policy formulation as agreement between community, government and private sector; (c) transparency and open management among three parties involved; (d) recognition and achievement awards to community groups that support restoration activities; (e) law enforcement on violators; (f). monitoring the effectiveness of ecosystem restoration activities; (g) facilitation of intercommunity conflict.
\end{abstract}

Key words: mangrove, co-management, Stakeholders, GSCA.

\section{INTRODUCTION}

Mangrove forests serve as an intermediary between the junction of land and sea and they are offering an array of goods and services to both marine life and people. Mangrove forests are commonly viewed as one of the most economically productive and bio-diverse ecosystems on Earth. Mangrove ecosystem is excellent fish nurseries. About $90 \%$ of the global mangroves are growing in developing countries and they are under the condition of critically endangered and nearing extinction in 26 countries.

In general, the mangrove areas are under heavy human pressure especially in the best developed mangroves that grow along humid sheltered tropical coastlines. Besides man-made pressures, the mangroves are degraded by environmental stress factors. Some estimates put global loss rates annually at one million hectare, with some regions in dangers of complete collapse (e.g. Kathiresan and Bingham, 2001). Herr at al ( 2015) mentioned that Every year, $1.9 \%$ of mangrove is lost, resulting in as much 240 million tons of $\mathrm{CO} 2$ per year is released into the atmosphere. The amount is equivalent to 588 million barrels of oil, 63 coal-fired power plants, 50.5 million passenger vehicles / year and 1.3 million coal-haul trains. 
Destruction of mangrove forests has become a major concern in Indonesia due to issues such as cutting for timber, fuel and charcoal. The local people collect food, timber and charcoal from mangrove forests. Mangrove ecosystem destruction and fragmentation is observed. The mangrove wood is highly suitable for chipboard industry and quality paper. As a result, several companies have been established for paper mills and chipboard factories in Indonesia. Within two years, the timber companies obtained timber by clearing 137,000 ha of mangroves (Erftemeijer et al., 1989). Data from Mastaller (1996) mentions that Indonesia in the period 1969-1986 which was estimated at the beginning of the mangrove area covering an area of 4.22 million ha become an area of 2.176 million hectares. Thus it is shrunk by $52 \%$.

Tuban district, located in East Java-Indonesia, has an area of mangrove 119.98 hectares. This regions is fairly intensive coastal erosion, and it leads to changes in the coastline.. Mangrove forests are damaged, because there is no flow of water coming into the area of Jenu. Changes in the coastline is very influenced by processes that occur in the area around the beach, where the beach is always adapting to different conditions. (Munoz et al, 2001). Utami et al (2013) states that in 1993 to 2009, 3.6 million square meters in the coastal area of Tuban lost due to abrasion.

The total area of mangrove forest in Jenu is $12 \mathrm{Ha} .10 \mathrm{Ha}$ of the area is good condition and the remaining area of 2 ha is suffered severe damage (Department of Marine and Fisheries Tuban, 2014). This damage is caused by sediment that has accumulated, so there is no flow of water that enters the mangrove area. This leads to damaged and cause a reduction in mangrove land and affect the growth of mangroves. (Pratiwi, 2016). The purpose of this study, firstly, is building co-management model among stakeholders involved. Secondly, to describe the model of co management to restore mangrove forests in coast of Jenu.

\section{STUDY AREA AND DATA}

To achieve the objectives above, it is done by distributed questionnaires to the parties Involved which includes respondents from government, private and public. The composition of the respondents can be seen in table 1 .

Table 1: The Types and Number of respondents

\begin{tabular}{lc}
\hline \multicolumn{1}{c}{ Types of respondents } & Number of Respondence \\
\hline PT. Power Plants Tanjung Awar-Awar Tuban & 3 \\
PT. Cements Gresik, Tbk. & 4 \\
Community Monitoring Group & 4 \\
Environmental Agency & 5 \\
Agricultural Agency & 3 \\
Social Agency & 3 \\
Fisheries and Marine Agency & 3 \\
Community Empowerment Agency & 4 \\
Planning and Development Agency & 4 \\
Total & 33 \\
\hline
\end{tabular}

As we know that mangrove forests have complex interaction with the surrounding environment, wherein the growth of individual species is influenced by both physical and chemical characteristics of soil and seawater (Satyanarayana et al, 2010).

For restoration purposes, we need to know drivers of vegetation structure. To know more clearly the conditions of the coastal village of Jenu, it will display the density of mangrove ecosystems in table 2, as follows: 
Table 2. The results of the identification of mangrove type on Mangrove Center Tuban

\begin{tabular}{c|c|c|r|r|c}
\hline Station & Species of mangrove & $\begin{array}{c}\text { Density } \\
\text { (stem Ha }-1)\end{array}$ & $\begin{array}{l}\text { Relative } \\
\text { Density } \\
\text { \%) }\end{array}$ & $\begin{array}{l}\text { Importance } \\
\text { Value } \\
\text { Index (\%) }\end{array}$ & $\begin{array}{c}\text { Level of } \\
\text { Mangrove } \\
\text { density }\end{array}$ \\
\hline 1 & Avicennia alba & 400 & 47.05 & 114.21 & \\
& $\begin{array}{c}\text { Rhizophora } \\
\text { mucronata }\end{array}$ & 300 & 35.2 & 109.04 & Rarely \\
Total & Rhizophora apiculata & 150 & 17.6 & 76.75 & \\
2 & Rhizopora mucronata & 300 & 100 & 300 & \\
& Rhizopora stylosa & 150 & 20 & 125.25 & Rarely \\
Total & Avicennia alba & 300 & 40 & 100.25 & \\
3 & & 750 & 100 & 300 & Rarely \\
& Rhizopora stylosa & 300 & 35.29 & 106.94 & \\
\hline \multirow{5}{*}{ Total } & Rhizopora mucronata & 350 & 41.17 & 114 & \\
\hline
\end{tabular}

Source: Pratiwi (2016)

Table 2 above states that at Station 1, located at the mouth of the river, has a type of sandy substrate rather muddy and lots of rubble. Density of mangrove species at station 1 of 850 stem $\mathrm{Ha}^{-1}$. This shows that the density is very rare. At station 2 , located in the area of the pond, has a kind of muddy substrate. Mangrove vegetation grows wildly as mangrove area made for pond method Silvofishery by local communities. Mangrove density in this region is the lowest compared to stations 1 and 3 with a value of 750 stem $\mathrm{Ha}^{-1}$. At station 3 is located in a residential area. The type of substrate is rather sandy muddy. The density of mangrove has a value of 800 stem Ha-1. Based on these data, it shows that in the village of mangrove jenu has low density.

Table 3: The results of measurements of environmental parameters on site observations

\begin{tabular}{c|l|c|c|c|c|c}
\hline \multirow{2}{*}{ No } & Parameters & \multicolumn{3}{|c|}{ Station } & Average & Environmental Quality Standard \\
\cline { 3 - 6 } & & 1 & 2 & 3 & & $7-8,5$ \\
\hline 1 & pH & 6.9 & 7.2 & 6.8 & 6.9 & Natural \\
\hline 2 & Salinity & 31 & 29 & 29.5 & 29.8 & $>5$ \\
\hline 3 & DO & 3.8 & 3.4 & 3.2 & 3.4 & Natural \\
\hline 4 & Temperature & 32 & 30 & 30.2 & 30.7 &
\end{tabular}

There are differences in temperature values on each station that has a varying location. Mangroves are ultimately limited by temperature but, at local and regional scales, variations in precipitation, tides, waves and river flow greatly determine their expanse and biomass.(Alongi, 2015). The distribution of mangrove species, in many cases, can be explained primarily by salinity gradients (Ball 1998; Ukpong 1994 in Joshi, 2003).

The results of measurements of salinity in mangrove areas Jenu Village range from $29 \%$ - 31 $\%$. According to Supriharyono (2000) mangroves can live and thrive in coastal salinity levels between $10 \%$ - $30 \%$. Station 1 has the highest salinity value of $31 \%$, while around $29 \%$ station 2 and station 3 around $29.5 \%$. Categories high salinity at Station 1 as close to the sea and there is no input of fresh water from the river mouth, while the stations 2 and 3 low salinity because it is located close to the river mouth. Salinity is one of the major environmental problems affecting plants of mangroves. The deleterious effects of salinity on plant growth are associated with low osmotic potential of soil solution causing physiological 
drought, nutritional imbalances and specific ion toxicity or combination of all these factors. Mangroves plants are facultative halophytes. Consequently they can still grow and function well even up to a salinity of 90 ppt, but shown best growth when salinity fluctuates between 5 and 75 ppt (Krauss et al., 2008).

The result of DO measurement ranged from $3.2 \mathrm{mg} / \mathrm{l}-3.8 \mathrm{mg} / \mathrm{l}$. It means that the number of human activities is intensively carried out around the village of Jenu mangrove forest. The more waste that goes into the water, the faster decrease in the concentration of DO (Hermawan et al. 2007). The higher the density of mangroves in a location, the content of dissolved oxygen in the water is also higher. The distributions of dissolved oxygen in estuaries are affected by different physical parameters like turbulence, atmospheric pressure, surface re aeration, river flow, and estuarine circulation. The overall partitioning of oxygen between the atmosphere and the water is sensitive to mixing and biological production, as well as temperature and salinity. The solubility of oxygen decreases as temperature and salinity increase and is more dependent on temperature variation than on salinity variation (Pinet, 2006; Sarmiento and Gruber, 2006 in Mocuba, 2010).

The results of $\mathrm{pH}$ measurement in mangrove areas Jenu village ranged from 6.8 to 7.2 . This is according to Boyd (1988) stated that generally natural waters have a pH range between 6.5 - 9 . Sadat (2004) states that the mangrove ecosystem can grow well in waters that have a pH range between 6.0 to 9.0. Station 1 has a pH value of 6.9 and station 2 has the highest $\mathrm{pH}$ of 7.2 and 3 stations of 6.8. The degree of acidity $(\mathrm{pH})$ of the water indicates that the environmental conditions on each station has to the low $\mathrm{pH}$, but it is not found the phenomenon of pollution. Low of $\mathrm{pH}$ due to the effects of water circulation. The $\mathrm{pH}$ value of the water is one of the factors that could affect marine productivity, where waters with a $\mathrm{pH}$ of 6.5-7.5 including productive waters, with a $\mathrm{pH}$ of 7.5-8.5. $\mathrm{pH}$ of this group are in waters that have a very high productivity. While,the waters with a $\mathrm{pH}$ greater than 8.5 is classified as no longer productive waters (Wardoyo, 1975). Based on the data presented by Pratiwi (2016) above that the condition of mangroves located in Jenu categorized severely damaged with the amount of 225 Stem Ha$^{-1}$. Such condition is called severely damage accordance with the guidelines inventory and identification of critical areas mangrove Department of Forestry (2005). The value of

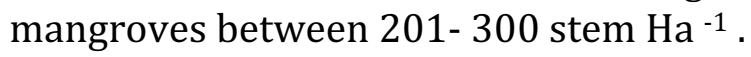

To overcome the problem of damage to mangrove forests in Jenu, it is used the model by using an approach called Generalized Structured Component Analysis (GSCA). GSCA offers a global least squares optimization criterion, which is consistently minimized to obtain the estimates of model parameters. In addition, GSCA handles more diverse path analyses, compared to PLS. Jung (2011) mentioned that dynamic generalized structured component analysis combines generalized structured component analysis (Hwang and Takane, 2004 in Jung, 2011) with a multivariate autoregressive model in a unified framework. Jung et al (2012) mentioned that Dynamic GSCA is a component-based method which combines the original GSCA and a multivariate autoregressive model in a unified framework to account for dynamic nature of data taken over time.

\section{METHODS}

To restore Jenu Coastal Region, it is required the intervention of the government of the village Jenu and Tuban regency government. In addition, the role of the community is especially important to support government programs related to the subsistence of the community and the preservation of the coastal environment. Whereas, the role of the private sector in this case is PT Semen Gresik and PT Power Plant Awar-Awar, located in the coastal village of jenu, is very strategic role. 


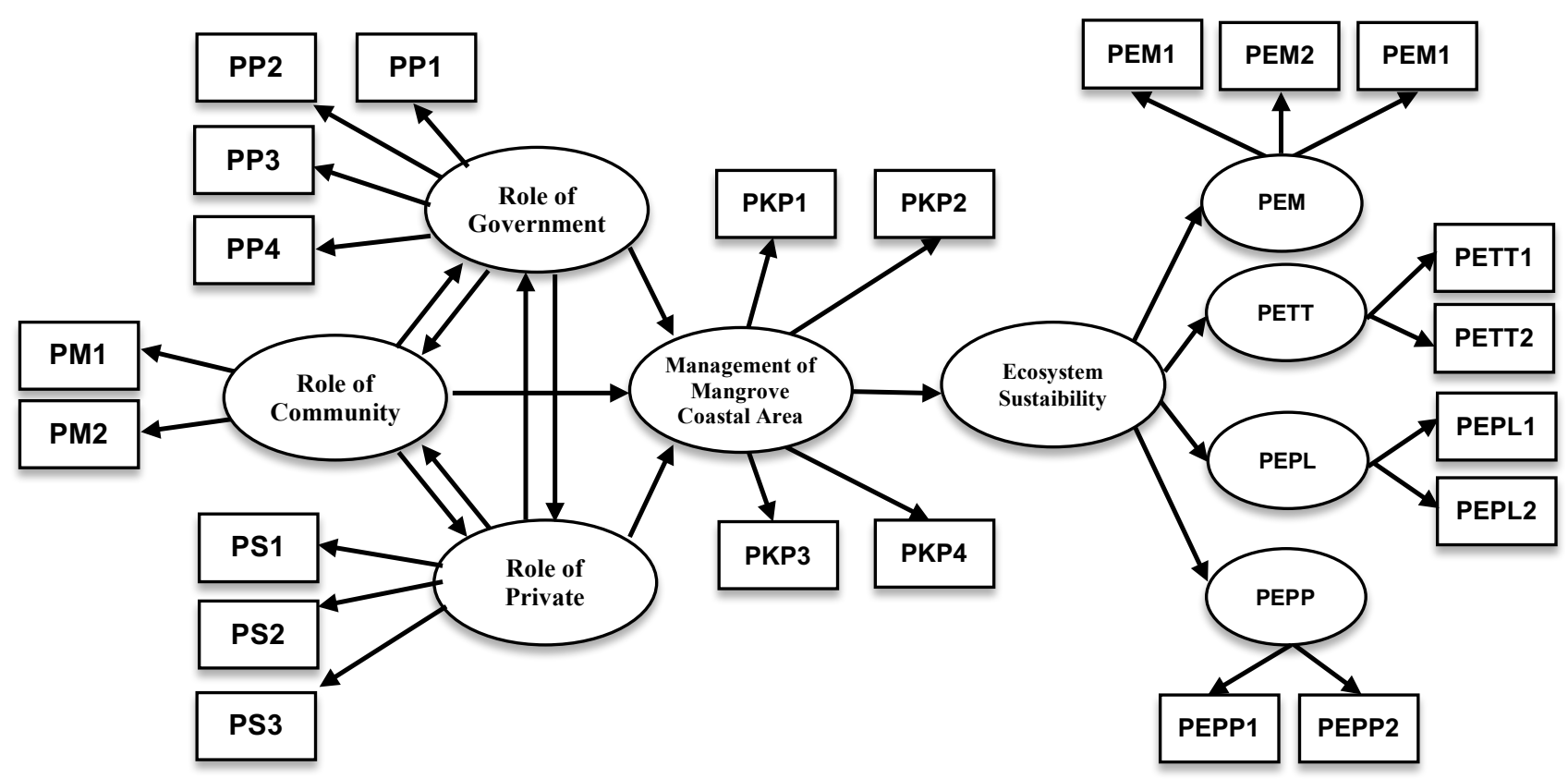

Figure 1: Model of Stakeholders Involvement to support Mangrove ecosystems Sustainability

Remarks:

PP: The Role of Government

PP1: Implementation

PP2: Supervision

PP3: Evaluation

PP4: Planning

PM: Role of Civil Society

PM1: Implementation

PM2: Supervision

PS: The Role of Private

PS1: Synergy

PS2: Preservation

PS3: Implementation
PKP : Coastal zone management

PKP1: Involvement

PKP2: Availability of Funds

PKP3: Synergy

PKP4: Monitoring and Evaluation

KEM: Mangrove Ecosystem Sustainability

KEM1: Reduced Damage to ecosystems

KEM2: Small Fish Seed Rises

KEM3: Sage and Responsible Society

KETT: Coral Reef Ecosystem Sustainability

KETT1: Cover healthy reef

KETT2: Coral Reef preserved

KEPL: Seagrass Ecosystems Sustainability

KEPL1: Seagrass healthy

KEPL2: Seagrass preserved

KEPP: Ecosystem Sustainability of beach sand

KEPP1: Garbage strewn slightly

KEPP2: clean sand beach

\section{RESULTS AND DISCUSSION}

After measuring the mangrove type, both the density and the mangrove species including the level of damage and the measurement of the quality of the waters either pH, salinity, DO and temperature, it can be concluded that mangrove condition in the village of Jenu has a very poor quality. For that required mangrove restoration to restore the condition of mangrove forest as before, although it is very difficult to be realized. This caused serious salinisation of the coastal land soil that will last for years, destroyed crops and forced many local people to looking for additional work alternatives elsewhere. Fisheries products are declining, and fishermen are trapped in poverty. To overcome the problem of poverty in the coastal areas, required cooperation of all parties. Mangrove restoration and management is one such endeavor that could result in a multitude of environmental, social, and economic benefits to the coastal 
communities (Wietsen, 2012). As stated by Berkes (1989) and Pomeroy and Williams (1994) mentioned that Co-management is an evolving method of managing natural resources that involves the sharing of management responsibility and/or authority of a resource between the government as owners of the resource, and the local community as users of the resource. The location of the result study as seen below.

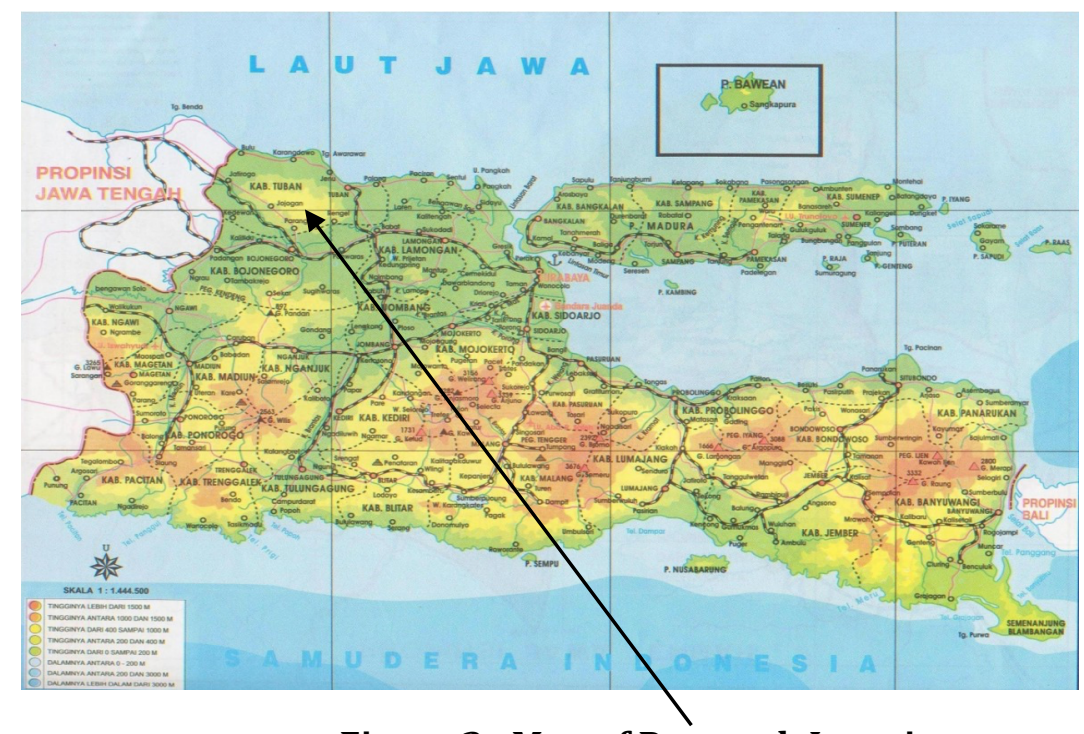

Figure 2 : Map of Research Location

The following are the results of GSCA analysis to address issues at the coast of Jenu. The main problem is the destruction of mangroves that grew massively as a result of anthropogenic and natural factors.

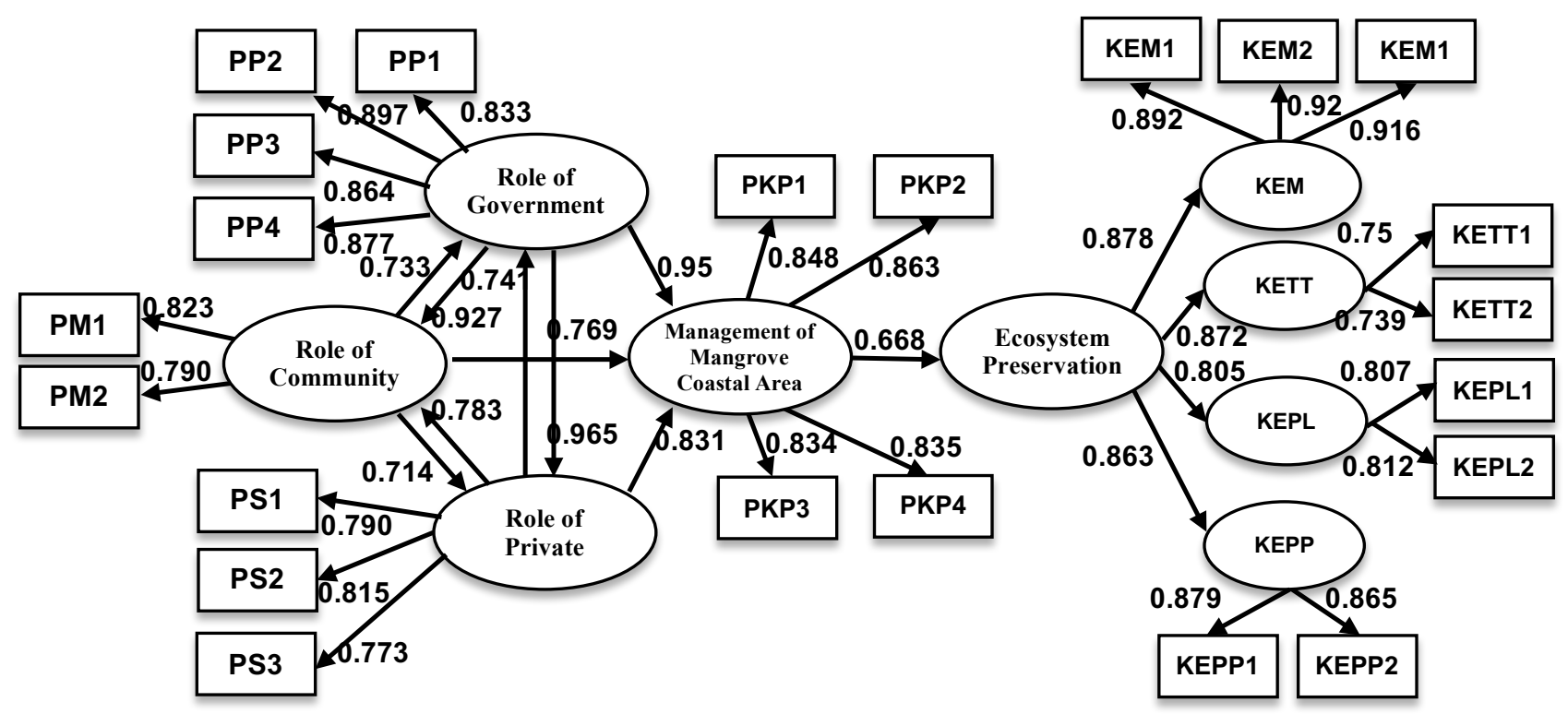

Figure 3: Diagram of Path

The evaluation of the measurement model (outer model) with a view convergent validity, discriminant validity, composite reliability, and value AVE. Measure of fit in the measurement model aims to test whether valid and reliable research instrument. 
Table 4: The measurement model

\begin{tabular}{|c|c|c|c|c|c|c|c|c|}
\hline Variable & Dimension & $\begin{array}{c}\text { Loading } \\
\text { Dimension }\end{array}$ & AVE & Alpha & Item & $\begin{array}{l}\text { Loading } \\
\text { Item }\end{array}$ & AVE & Alpha \\
\hline \multirow{4}{*}{$\begin{array}{l}\text { Role of the } \\
\text { government }\end{array}$} & \multirow{4}{*}{ - } & \multirow{4}{*}{ - } & \multirow{4}{*}{-} & \multirow{4}{*}{ - } & PP1 & 0.833 & \multirow{4}{*}{0.756} & \multirow{4}{*}{0.919} \\
\hline & & & & & PP2 & 0.897 & & \\
\hline & & & & & PP3 & 0.864 & & \\
\hline & & & & & PP4 & 0.877 & & \\
\hline \multirow{3}{*}{$\begin{array}{l}\text { Role of } \\
\text { Community }\end{array}$} & - & \multirow{3}{*}{ - } & & \multirow{2}{*}{ - } & PM1 & 0.823 & \multirow{2}{*}{0.651} & \multirow{2}{*}{0.655} \\
\hline & & & & & PM2 & 0.79 & & \\
\hline & & & & & PS1 & 0.79 & \multirow{3}{*}{0.615} & \multirow{3}{*}{0.873} \\
\hline \multirow[t]{3}{*}{ Role of Private } & \multirow[t]{3}{*}{-} & \multirow[t]{3}{*}{-} & \multirow[t]{3}{*}{-} & \multirow[t]{3}{*}{-} & PS2 & 0.815 & & \\
\hline & & & & & PS3 & 0.773 & & \\
\hline & & & & & PKP1 & 0.848 & & \\
\hline \multirow{3}{*}{$\begin{array}{l}\text { Management } \\
\text { Coastal Area }\end{array}$} & & \multirow{3}{*}{ - } & \multirow{3}{*}{ - } & \multirow{3}{*}{-} & PKP2 & 0.863 & \multirow{3}{*}{0.714} & \multirow{3}{*}{0.794} \\
\hline & - & & & & PKP3 & 0.834 & & \\
\hline & & & & & PKP4 & 0.835 & & \\
\hline \multirow{9}{*}{$\begin{array}{l}\text { Preservation } \\
\text { Ecosystems }\end{array}$} & \multirow{3}{*}{ KEM } & \multirow{3}{*}{0.878} & & & KEM1 & 0.892 & \multirow{3}{*}{0.716} & \multirow{3}{*}{0.799} \\
\hline & & & & & KEM2 & 0.92 & & \\
\hline & & & & & KEM3 & 0.916 & & \\
\hline & \multirow{2}{*}{ KETT } & \multirow{2}{*}{0.872} & & & KETT1 & 0.75 & 0926 & 0917 \\
\hline & & & 0.731 & 0.905 & KETT2 & 0.739 & 0.520 & (1) \\
\hline & KEPL & 0.805 & & & KEPL1 & 0.807 & 0.806 & 0.756 \\
\hline & & & & & KEPL2 & 0.812 & & \\
\hline & & & & & KEPP1 & 0.879 & 0887 & 0871 \\
\hline & KEPP & 0.863 & & & КЕРP2 & 0.865 & $0.00 \%$ & $0.0 / 1$ \\
\hline
\end{tabular}

Based on the above analysis, it is known that all the indicators generate value loading factor $>$ 0.5 . Then the value AVE all variables $>0.5$, and Cronbach's alpha values is $>0.6$. Thus the indicators that measure of the role of government, public, and private, as well as coastal area management and ecosystem sustainability are declared valid and reliable.

The role of government variables, indicators for monitoring (PP2) has a value of loading factor of the greatest and performance indicators (PP1) has the lowest loading value. It shows indicators supervision (PP2) contributed the most in the variable measuring the role of government, while the indicator of the implementation of PP1) has contributed the most in the variable measuring the role of government.

The role of community variables, performance indicators (PM1) has a value of loading factor of the greatest. While, the supervision indicators (PM2) has the lowest loading value. It shows that the performance indicators (PM1) contributed the most in the variable measuring the role of society. Whereas, the indicators for monitoring (PM2) has contributed the most in measuring variables of public role.

The role of private variables, indicators of sustainability (PS2) has a value of loading factor of the greatest and performance indicators (PS3). It has the lowest loading value. It shows indicators of sustainability (PS2) contributed to the most in measuring variables private role. While, indicators of implementation (PS3) has contributed to the most measure variables private roles. In the coastal area management variables, the indicators of the availability of 
funds (PKP2) has a value of loading factor of the greatest and indicators of synergy (PKP3) has the lowest loading value. It shows that the indicator of availability of funds (PKP2) contributed to the most in measuring variables coastal area management. While, indicators of synergies (PKP3) contributed to the most coastal area management measure variables.

Table 5: Goodness of Fit Model and Structural Model.

\begin{tabular}{c|c|c|c|c|c}
\hline Exogen & Endogen & Estimate & CR & FIT & GFI \\
\hline PP & PM & 0.927 & $18.2^{*}$ & & \\
PP & PS & 0.965 & $14.0^{*}$ & & \\
PP & PKP & 0.95 & $19.0^{*}$ & \\
PM & PP & 0.733 & $22.9^{*}$ & & \\
PM & PS & 0.714 & $10.8^{*}$ & 0.624 & \\
PM & PKP & 0.769 & $32.0^{*}$ & & \\
PS & PP & 0.741 & $14.8^{*}$ & & \\
PS & PM & 0.783 & $27.0^{*}$ & & \\
PS & PKP & 0.831 & $27.7^{*}$ & & \\
PKP & KE & 0.668 & $5.7^{*}$ & & \\
\hline
\end{tabular}

The results of the analysis are listed in the table above were obtained GFI value of 0.956 . This shows the value of GFI $>0.9$ which states that the model is formed GSCA feasible to use to predict. FIT value of 0.624 indicating that the range of data can be explained by the model amounted to $62.4 \%$, while the remaining $37.6 \%$ is explained by other variables outside the study. The analysis of the above table also informs the role of government influence on the role of community produced a coefficient of 0.927 with the value of the critical ratio (CR) 18.2 * (asterisk or CR>2:00). This means that there is a significant influence on the role of the public and the role of government. The government's role in preserving the coast of Jenu could improve the community's role in conserving mangrove forests.

The influence of the government's role to the private sector's role is generated coefficient of 0.965 with the value of the critical ratio (CR) of $14.0 *$ (asterisk or CR> 2:00). This means that there is a significant influence on the role of government to the role of the private sector. It means that the better the role of governments to conserving Jenu coast, the better the role of the community to collaborate conserve mangrove forests.

The influence of the government's role on the management of coastal areas is resulting coefficient of 0.95 with the value of the critical ratio (CR) of $19.0 *$ (asterisk or CR> 2:00). This means that there is a significant influence on the government's role to the management of coastal areas. It means that the better the role of the government and thus tend to improve coastal management of Jenu.

The influence of the role of society towards the role of government produced a coefficient of 0.733 with the value of the critical ratio (CR) of $22.9 *$ (asterisk or $\mathrm{CR}>2.00$ ). This means there is a significant influence on the public role of the role of government. The better the community's role in preserving coast of Jenu, it tends to increase the government's role in preserving the mangrove forests. 
The influence of the public role of the private sector's role is generated coefficient of 0714 with the value of the critical ratio (CR) of $10.8 *$ (asterisk or CR> 2:00) .This means that there is significant influence society's role to the role of the private sector. The better the community's role in preserving coast of Jenu, it tends to increase the private sector's role in preserving the coast of Jenu.

The influence of the role of society to coastal management is resulting coefficient of 0.769 with the value of the critical ratio (CR) of $32.0 *$ (asterisk or CR> 2:00). This means there is a significant influence on the public role of coastal management. The better the role of the community then tend to improve management of coastal areas. The influence of the private sector role to the role of government produced a coefficient of 0.741 with the value of the critical ratio (CR) of $14.8 *$ (asterisk or CR> 2:00).

This means there is a significant influence of the private sector's role to the role of government. The better the private sector's role in preserving the coast Jenu, it tends to increase the government's role in preserving the mangrove forests. The influence of the private sector role to the role of community produced a coefficient of 0.783 with the value of the critical ratio (CR) of $27.0 *$ (asterisk or CR> 2:00). This means there is a significant influence on the role of public private participation. The better the private sector's role in preserving the coast Jenu, it tends to increase the community's role in conserving coastal mangroves. The influence of the private sector's role to the management of coastal areas is resulting coefficient of 0.831 with the value of the critical ratio (CR) of $27.7^{*}$ (asterisk or CR> 2:00). This means there is a significant influence on the role of private sector management of coastal areas. The better the role of the private sector tend to improve management of coastal areas.

Effect of coastal management to the conservation of ecosystems is resulting coefficient of 0.668 with the value of the critical ratio (CR) of $5.7 *$ (asterisk or CR> 2:00). This means there is a significant effect of coastal zone management to ecosystem sustainability, the better management of coastal areas tend to improve the sustainability of ecosystems. The role of government is known to be variables that most influence on the role of society, the role of the private sector and coastal management. On the other hand the role of the community has a dominant influence on the role of government.

Rudianto (2015) stated that to build collaborative management, it is needed a conducive conditions with prerequisite as follows: a) equality in deliberation; (b) public policy formulation as agreement between community, government and private sector; (c) transparency and open management among three parties involved; (d) recognition and achievement awards to community groups that support restoration activities; (e) law enforcement on violators; (f). monitoring the effectiveness of ecosystem restoration activities; (g) facilitation of intercommunity conflict.

To describe the model of co management into seven (7) elements as mentioned by Rudianto above, the translation can be seen in table 6 . 
Table 6: The Role of Parties Involved in Co-Management

Prerequisite of Collaborative Management

(a) equality in deliberation

The Role of parties involved in

mangrove restoration

a. The role of government is to create opportunities for all members of a population to make meaningful contributions to decision-making and to seeks to broaden the range of people who have access to such opportunities

b. The role of community allows for citizens to voice and to discuss different view-points. The citizen has the biggest burden to bear in public deliberation, because the diversity of the citizen's community democracy cannot function without that high expectation.

c. The Role of Private can uniquely leverage nonprofit partnerships and investment in order to achieve sustainable development.

(b) public policy formulation as agreement between community, government and private sector (c) transparency and open management among three parties involved; a. The role of government will provide encouraging the delivery and uptake of the policy to as well as delivering local government programs under agreement to restore mangrove forests, and developing a local government implementation plan.

b. The role of community is to ensure that the main purpose of restoring mangrove forest is to bring measurable, permanent improvements to the lives of affected local residents, particularly those in low-income in surrounding coast of Jenu.

c. The role of private players an important role in restoring mangrove forests - as a cause and catalyst of strife, and as an integral part of restoring and maintaining mangrove grows

a. The role of government often credited with generating government accountability. Transparency often allows citizens of a democracy to control their government, reducing government corruption, bribery and other malfeasance. Transparent government allows for the dissemination of information, which in turn helps produce greater knowledge and societal progress

b. The role of Community is recognized that transparency and accountability are important characteristics of a community. The ultimate goal is to improve the lives of community by providing quality services and promoting restoring mangrove forest in an open, competitive, and fair manner.

c. The role of private has a vital interest in restoring mangrove forest and improved service restoring. Integrated and transparent financial management systems help local governments qualify for necessary allocate budget together from other sources outside budget form local government. (d) recognition and achievement awards to community groups that support restoration activities

a. The role of government is recognized the local community programs or processes that demonstrate innovation, excellence, and success in the community's organization, including enhancement in the quality of life for community around the mangrove forests.

p. The role of community can show a good partnership with local government and create trust to private sector related with excellent program to restore mangrove forests. To create small scale business improvement, redevelopment local community institution, encouraging local economic development corporations.

. The role of private should have initiatives that focus on helping and growing existing small businesses to encourage within communities to develop local economic in coast of Jenu.

(e) law enforcement on violators; a. The role of government officials and communities carry out joint patrols against illegal logging of mangrove and wood theft. The government requires some degree of formal recognition of the 


\begin{tabular}{|c|c|}
\hline & $\begin{array}{l}\text { community's role, and the willingness of the official law } \\
\text { enforcement agencies to suppress violations once detected. } \\
\text { Reallocating rights and responsibilities are essential if } \\
\text { communities are to be effectively engaged in law enforcement. } \\
\text { b. The role of community is very strategic to control deforestation, } \\
\text { and continued proliferation of forest crimes given by the } \\
\text { government. Law enforcement is essential to ensure that the } \\
\text { benefits of mangrove forest exploitation are sustained and } \\
\text { distributed fairly. But stronger law enforcement has often been } \\
\text { practiced at the expense of the poor, who are easier targets for } \\
\text { suppression than the rich and powerful } \\
\text { c. The role of private is engaging local communities in law } \\
\text { enforcement that makes sense because communities are often } \\
\text { better placed than law enforcement officers to detect illegal } \\
\text { forest exploitation by outsiders. }\end{array}$ \\
\hline $\begin{array}{l}\text { (f). monitoring the effectiveness of } \\
\text { ecosystem restoration activities; }\end{array}$ & $\begin{array}{l}\text { a. The role of government requires the guidance of value-based } \\
\text { standards in their design, implementation, monitoring and } \\
\text { evaluating. The government needs instrument that is being used } \\
\text { to integrate and coordinate decision-making process, especially } \\
\text { for monitoring program. The government should have qualities } \\
\text { of anticipation, an orientation to the long-term, a vision of } \\
\text { sustainability for monitoring, and they should foster cultures of } \\
\text { learning and experimentation in order to develop adaptive } \\
\text { capacities among parties involved } \\
\text { b. The role of community should adopt the design and } \\
\text { implementation of monitoring policy that needs to take into } \\
\text { account of and be suited to the particularities of local } \\
\text { conditions. } \\
\text { c. The role of private to monitor implementation effectively is } \\
\text { influenced by funding availability and continuity as well as } \\
\text { succession monitoring planning. Effective business system is } \\
\text { needed to support the successful of monitoring system. }\end{array}$ \\
\hline $\begin{array}{l}\text { (g) facilitation of intercommunity } \\
\text { conflict }\end{array}$ & $\begin{array}{l}\text { a. The role of government is to reduce intercommunity conflict and } \\
\text { it is depending on effective implementation that is influenced by } \\
\text { executive skills and leadership; The important thing is no } \\
\text { individual interest to cope with intercommunity conflict. } \\
\text { Community engagement at community-level peace building is a } \\
\text { laudable sound. } \\
\text { b. The role of community has the right kind of freely flowing } \\
\text { information, together with effective communication,. It can } \\
\text { stimulate the creativity and flexibility necessary to respond to } \\
\text { intercommunity conflict situations. Community can encourage } \\
\text { intercommunity dialogue, because they now the local wise. } \\
\text { c. The role of private: more emphasis on communication both } \\
\text { internally within the peacekeeping individual/organization and } \\
\text { with other supporting intercommunity reconciliation. When the } \\
\text { situation is facing a lack of commitment by local community or } \\
\text { government, all actors must continue to build confidence and } \\
\text { promote channels of communication among community } \\
\text { involved in conflict, and encourage through all possible means a } \\
\text { local, inclusive dialogue. }\end{array}$ \\
\hline
\end{tabular}

\section{CONCLUSIONS}

Contreras et al (2002) mentioned that areas where there is prevalence of global or national non-market values such as biodiversity, water, and soil protection, and conservation of the natural heritage, will tend to remain as the main responsibility of the state. In these cases, policies may give preferential attention to those areas located in inaccessible places, as these are easier to protect. In terms of coast of Jenu to restore mangrove forests based on comanagement, the result shows that the government is the main actors to accelerate mangrove restoration. Whereas, the local community and private should encourage the government role 
to create close collaboration. The main principle to create co-management is by reforming policies for restoring mangrove forests. It may also focus on obtaining a better coincidence between the traditional rights of local and indigenous populations and the "formal" legal system of forestland ownership and access.

Local government, community, and the private sector are working together to serve the public in an ethical and open manner that engenders accountability. Local governments play a critical role in facilitating transparency and accountability. Community and the private sector, as well as local government-must be held to standards of transparency and accountability. All three must be actively engaged in identifying solutions and promoting transparency in their own organizations. All three have a responsibility to communicate openly and work together to facilitate change in Jenu area.

Building such partnerships implies fundamental changes in the way state authorities perceive and treat those who live in, and depend on, the mangrove forest. This means going beyond what is currently characterized as "community forestry," which often means no more than paying local community to plant trees on degraded land, to a partnership that capitalizes on their respective strengths and capacities.

\section{ACKNOWLEDGEMENTS}

The corresponding author are gratefully to thank to Rector of Brawijaya University- Professor Dr. Ir Mohammad Bisri to give me a chance to conduct my research. I also would like to thank to Mr Aulia Luqman Azis whose help me to accelerate my research.

\section{References}

Alongi, Daniel. 2015. Carbon sequestration in mangrove forests. Future Science. Research Gate. Australian Institute of Marine Science, PMB 3, Townsville MC, Queensland 4810, Australia. ISSN. 1758. 3004.

Ball, M.C. 1998. Mangrove species richness in relation to salinity and water logging: a case study along the Adelaide River floodplain, northern Australia. Global Ecology and Biogeogrpahy Letters 7: 73-82

Berkes, Fikret, Peter George and Richard J. Preston. 1991. Co-Management. The Evolution in Theory and Practice of the Joint Administration of Living Resources. Alternatives 18(2):12-18.

Boyd, C.E., 1988. Water Quality Management For Pond Fish Cultur. Developments In Aquaculture And Fisheries Science, Volume 9. Auburn University

Contreras, Arnoldo , Hermosilla. 2002. Law Compliance in the Forestry Sector An Overview. World Bank Institute, WBI Working Papers.

Department of Fisheries and Marine Tuban. 2014. Vegetation Mangrove Rehabilitation Project Report. Fisheries and Maritime Tuban.

Herr, D. T. Agardy, D. Benzaken, F. Hicks, J. Howard, E. Landis, A. Soles and T. Vegh (2015). Coastal "blue" carbon. A revised guide to supporting coastal wetland programs and projects using climate finance and other financial mechanisms. Gland, Switzerland: IUCN. ISBN: 978-2-8317-1762-3. DOI: http://dx.doi.org/10.2305/

IUCN.CH.2015.10.en

Erftemeijer, P. Allen,G. and Zuwendra. 1989. Preliminary resource inventory of Bintuni Bay and recommendations for conservation and management. In: Dir.Gen. Forest Protection and Nature Conservation and Asian Wetland Bureau, Bogor, Indonesia, 1 - 151.

Hermawan et.al. 2007. Vegetation Species Diversity and Structure of Mangrove in the village of Padang Cermin subdistrict Sidodadi Pesawaran District, Lampung Province. Faculty of Fisheries and Marine Sciences, University of Diponegoro. Semarang mangrove forest in Sumatra. PPLH. Bogor Agricultural Institute. Bogor.

Herr, D. T. Agardy, D. Benzaken, F. Hicks, J. Howard, E. Landis, A. Soles and T. Vegh. 2015. Coastal "blue" carbon. A revised guide to supporting coastal wetland programs and projects using climate finance and other financial mechanisms. Gland, Switzerland: IUCN. 
Howard, J., Hoyt, S., Isensee, K., Telszewski, M., Pidgeon, E. (eds.) 2014. Coastal Blue Carbon:Methods for assessing carbon stocks and emissions factors in mangroves, tidal salt marshes, and seagrasses. Conservation International, Intergovernmental Oceanographic Commission of UNESCO, International Union for Conservation of Nature. Arlington, Virginia, USA.

Hwang, H., and Tanake, Y. 2004. Generalized Structured Component Analysis. Psycometrika, 69, 81-99.

Joshi, Hema., M. Ghose. 2003. Forest structure and species distribution along soil salinity and pH gradient in mangrove swamps of the Sundarbans. Tropical Ecology 44(2): 197-206, 2003 ISSN 0564-3295. Downloaded at http://www.tropecol.com /pdf/open/PDF_44_2/44207.pdf.

Jung, Kwang Hee . 2011. Dynamic GSCA (Generalized Structured Component Analysis): A Structural Equation Model for Analyzing Effective Connectivity in Functional Neuroimaging. A thesis submitted to McGill University in partial fulfillment of the requirements of the degree of Doctor of Philosophy. McGill University Montreal June 2011.

Jung, Kwanghee., Yoshio Takane., Heungsun Hwang., and Todd S. Woodward. 2012. Dynamic GSCA (Generalized Structured Component Analysis) With Applications to The Analysis of Effective Connectivity in Functional Neuroimaging Data. Department of Psychiatry, University of British Columbia, BC Mental Health and Addictions Research Institute in Child and Family Research Institute Building, Room A3-112, 938 West 28th Avenue, Vancouver, BC V5Z 4H4, Canada.

Kathiresan, K. and Bingham B. L. 2001. Biology of mangrove and mangrove ecosystems. Advances in Marine Biology, 40: 81 - 251.

Krauss KW, CE Lovelock, KL McKee, L López-Hoffman, SML Ewe and WP Sousa. 2008. Environmental drivers in mangrove establishment and early development: A review. Aquatic Botany 89(2), 105-127

Mastaller, M. (1996). Destruction of mangrove wetlands - causes and consequences. Natural Resources and Development, 43 (44):37 - 57.

Mocuba, Jeremias.2010. Dissolved Oxygen Demand in The Waters close to The Quelimano Sewage Discharge. Master Thesis in Chemical Oceanography Geophysical Institute, University of Bengen, Norway

Munoz-Perez, J. J., Medina, R., dan Tejedor, B., 2001. Evolution of longshore beach contour lines determined by the E.O.F. method. Jurnal Scientia Marina. Vol. 65. 393-402p.

Pratiwi Dwi Puput. 2016. Restoration of mangrove ecosystem-based management in the Mangrove Center Tuban, District Jenu, Tuban. Thesis, Fisheries and Marine Resources, University of Brawijaya.

Pomeroy, R.S. and M. Williams. 1994. Fisheries Co-Management and Small Scale Fisheries: A Policy Brief. Manila: ICLARM.

Rudianto, Ismadi, Ade Yamindago. 2015. Restoration Coastal Ecosystem - A Case Study in Malang and Gresik Regency, Indonesia. Journal of Coastal Conservation-Planning and Management. ISSN 1400-0350. J Coast Conserv. DOI 10.1007/s11852-015-0373-0. Springer.

Sadat, A. 2004. Mangrove Ecosystem Condition based Environmental Quality Indicators and Measurement Morphometrics Penet Way Leaves in East Lampung Regency of Lampung Province. Department of Marine Sciences and Technology Faculty of Fisheries and Marine Science, Bogor Agricultural University, Bogor.

Satyanarayana, Behara., Indra F. Idris., Khairul A Mohammad., Mohd-L Husain., Noor AM Shazili., Farid DahdouhGuebass. 2010. Mangrove Species Distribution and Abundance in relation to Local Environment Settings: a case study at Tumpat, Kelantan Delta, East Coast of Peninsular Malaysia. Authors'Personal Document. Botanica Marina 53 (2010):79-88, 2010 by Walter de Gruiter. Berlin. Newyork. DOI 10.1515/BOT.2010.006

Supriharyono. 2000. Preservation and Management of Natural Resources in Tropical Coastal Zone. PT Gramedia Pustaka Utama. Jakarta, Indonesia.

Ukpong, I.E. 1994. Soil-vegetation interrelationships of mangrove swamps as revealed by multivariate analyses. Geoderma 64: 167-181.

Utami, Veranita Hadyanti Utami and Adjie Pamungkas. 2013. Identification Zone in the Coastal Abrasion Vulnerable to Tuban. Study Program of Urban and Regional Planning, Faculty of Civil Engineering and Planning, the Surabaya Institute of Technology (ITS). JOURNAL OF ENGINEERING POMITS Vol. 2, No. 2 (2013) ISSN: 2337-3539 (Print 2301-9271)

Wardoyo.1975. Practical Guide Coastal Rehabilitation: An Experience Rehabilitating Coastal Area. Wetlands International - Indonesia Program, Bogor. 

40.

Witsen, deidre. 2012. Mangrove Restoration and Management in Djibouti: Criteria and Conditions for Success. Virginia Polytechnic Institute and State University Master of Natural Resources Major: Natural Resources. Downloaded http://pdf.usaid.gov/pdf_docs /pnaed179.pdf on 12 December 2018. 